\title{
ABSURDITY IN PUTU WIJAYA'S SHORT PLAY
}

\author{
Surya Farid Sathotho \\ Institut Seni Indonesia Yogyakarta, Indonesia \\ suryafarid@isi.ac.id
}

\begin{abstract}
Abstrak: Drama pendek (Drapen) merupakan format karya Putu Wijaya yang mutakhir. Drama tersebut hanya berkisar antara dua sampai duabelas halaman. Dari jumlah halaman yang ada, diasumsikan pementasan drapen hanya akanberlangsung lima sampai sepuluh menit. Meski hanya berdurasi pendek, Putu Wijaya konsisten dengan konsep estetika teror. Konsep ini bila dirunut lebih jauh merupakan turunan dari konsep teater absurd. Untuk melihat kemungkinan pementasan drapen tersebut akan dilakuk ananalisis struktur dan tekstur drapen yang dipilih secara acak. Analisis dilakukan dengan pendekatan teoritis yang melihat adanya teror pada struktur dan tekstur dalam sebuah naskah drapen. Diharapkan hasilnya akan memperlihatkan apakah drama pendek tersebut memenuhi kaidah dramaturgi untuk dipentaskan di atas panggung
\end{abstract}

Kata kunci: Drama Pendek, Teater Absurd, Putu Wijaya

\begin{abstract}
Short play known as Drama Pendek (Drapen) is the latest form of Putu Wijaya's work. The play only ranges from two to twelve pages. From the number of pages, it is assumed that the drapen performance will only last five to ten minutes. Although only a short duration, Putu Wijaya is consistent with the aesthetic concept of terror. This concept, if traced further, is a derivative of the concept of the theatre of the absurd. An analysis of the structure and texture of randomly selected drapes will be carried out to see the possibility to perform the drapen. It is carried out with a theoretic al approach that sees the terror in the structure and texture in a drafted text. Hopefully, the results will show whether the short play meets the rules of dramaturgy to be performed on stage
\end{abstract}

Key words: Short play, Theatre of the Absurd, Putu Wijaya

\section{Preliminary}

Putu Wijaya is a versatile artist who actively works in many fields. Besides being famous as a playwright, Wijaya is also a writer of short stories, novels, screenplays and soap operas, and a theatre and film director. Over more than forty years, his work has undergone many changes. His most recent work is in the form of a short play. In 2018, Putu Wijaya received the title of Doctor Honoris Causa from ISI Yogyakarta. Short play (drapen) is the style of a script recently written by Putu Wijaya. In the book 100 DRAPEN which Teater Mandiri published in April 2018, he collected one hundred of his works in a book as thick as xiv
+721 pages. The book consists of 1 of 2 pages play, 1 of 3 pages play, 11 of 4 pages play, 48 of 6 pages play, 28 of 8 pages play, 4 of 10 pages play, and 7 of 12 pages playa total of 100 short plays (Wijaya, 2018).

Judging from the number of pages, it is evident the difference with Putu Wijaya's previous plays. Those written in the early days of his work (eg Lautan Bernyanyi, Bila Malam Bertambah Malam), or in later works (Aduh, Dag Dig Dug, Gerr, Aum, etc.). Even a Jprut performance in 2018, the same year Putu Wijaya's 100 DRAPEN was published. Putu Wijaya's previous plays took 1-2 hours to perform, while Jprut's was staged 45 minutes at Taman Ismail Mazuki, Jakarta. 
However, according to Bambang Sugiharto, no matter how long or short the play he wrote, he remained consistent with the so-called aesthetic terror (Wijaya, 2018).

According to Wijaya in a discussion at TIM, what is meant by terror is not something that should be synonymous with bloody violence. He gave an example that if he was constantly asked by his wife whether to go to the supermarket or not, it was called terror. If traced back, Putu Wijaya's aesthetic concept of terror develops the absurd theatre concept that Martin Esslin has discussed in The Theater of The Absurd (Esslin, 1967).

Interesting to discuss are; how Putu Wijaya terrorized the audience with a drama performance based on his drapen. Is there enough time to build an aesthetic of terror that requires repeated repetition of very short plays based on a text of no more than ten pages? Referring to the length of the plays in the book, assume that the performances shown are only five to ten minutes long. The results of this study expecting to be a source to formulate a directing concept for Putu Wijaya's short drama.

It will see the elements that build them, known as structure and texture, to examine these plays. The structure and texture of the drapen are studied to see if Putu Wijaya's short plays dramaturgically met the rules to be performed on stage.

\section{Previous Research}

Fairly comprehensive research upon Putu Wijaya was carried out by Adi Setijowati, with the title The Nyali of Putu Wijaya's Work in the Perspective of Symbolic Violence Pierre Bourdieu: A Study of Hermeneutics by Paul Ricoeur (Setijowati, 2018). This research is a dissertation at Airlangga University. Although it does not discuss Putu Wijaya's aesthetics of terror directly, this article is beneficial in understanding Putu Wijaya's works in hermeneutics.
Another research that discusses the structure and texture of a play is the Analysis of the Structure and Texture of the Enemy of the Community by Henrik Ibsen Translated by Asrul Sani (Sathotho, 2008). As the title suggests, this study analyzes the plays by analyzing their structure and texture. This research model has similar methods and approaches with the research to be carried out, especially the analysis of the structure of the plays.

\section{Theoretical basis}

As an initial step of the analysis, Putu Wijaya's plays included literary works genres as novels, short stories, and poetry (Damono, 1978). In literary works, we recognize intrinsic elements in the form of characterizations, plots and themes. Furthermore, Boen S Oemarjati stated that structure is the main component and is the principle of unity of action concerning plot and characterizations (Oemarjati, 1974). From the elements that exist in the structure of a drama script, approaching drama with literary theory is beneficial. In other words, in line with Damono's statement, a drama before staged is essentially a literary work.

Structuralism theory examines literary works in their autonomy, apart from social, historical, biographical backgrounds, and others (Teeuw, 1984). Meanwhile, Kutha Ratna argues that definitively structuralism means understanding the elements, namely the structure itself... (Ratna, 2004). In this connection to dramatic texts, the elements of drama include themes, dialogues, events or events, background or setting, characterizations or characterizations, plots or plots, and language style (Ratna, 2004). In line with this, Goldman in Faruk mentions that literary works are a structure. However, the structure is not something static but the product of an ongoing historical process, structuring and destructuring that lives and is internalized by the people of origin of the 
literature concerned (Faruk, 1994). This statement implies an understanding that separating an artist from the mutual influence of his society is impossible. Society influences writers, authors influence society.

The next step in analyzing drapen of Putu Wijaya based on the concept of the theatre of the absurd as described by Martin Esslin in The Theater of the Absurd;

The theater of the Absurd, in the other hand, tends toward a radical devaluation of language, toward a poetry that is to emerge from the concrete and objectified images of the stage itself. The element of language still plays an important part in this conception, but what happens on the stage transcends, and often contradicts, the words spoken by the character (Esslin, 1967).

One of the circumstances described by Esslin could occur with the chaos and terror that Artaud had initially conveyed

A souvenir, a memento. Anarchy and chaos must be connected with a sense of order, which he (Artaud) devised in mind and not a physical technique. It is still appropriate to quote a phrase for those who call themselves students of Artaud: "cruelty is rigours", yes, cruelty is harsh, harsh! (Grotowski, 2002).

Furthermore, Putu Wijaya reformulated what he believed to be the forms of terror applies in the writing of his plays. For him, terror is a way to intensify his experience and expand his human perception. Terror is an ideology in his artistic attitude. Terror attempts to disturb the balance, tear up conclusions, beliefs, and norms so that the audience is free from the colonial mind, dogmatic violence, and spiritual bottlenecks, making humans wild (Wijaya, 2018).

His thoughts did not appear immediately but have existed since the 80 s through the statement "Short stories are a mental terror to humans being" in his creative writing credo (Wijaya, 1982).

Meanwhile, according to Kernodle, six elements support each other in a drama to establish a unity of action. The six elements are plot, characterization, theme, dialogue, mood and spectacle (Kernodle, 1967). The first three elements are known as structure, while the next three are texture. The texture of a drama is anything that can be heard by the ear, seen by the eye, and felt as a mood by the audience (Kernodle, 1967). The texture component consists of dialogue, spectacle and atmosphere. By its nature, the texture of a drama appears when it is staged. This distinguishes theater scripts from other literary works such as novels or short stories. In novels or short stories, this aspect of texture does not appear.

The possibilities of a text already exist from the structure of the text. Although the texture of the drama only appears when it is staged. The structure of the script has provided clues for the creation of the structure of the drama. In other words, the texture of drama is the embodiment of structure. In Acting and Stagecraft, Made Simple (Bowskill, 1973), Bowskill explains the position of the script from the point of view of the reader as part of society. The reader here can mean the director, actor or audience. This discussion is critical because the author discusses the analysis of a manuscript. Bowskill explains as follows:

The reader also has a creative process. If the play is to work for a reader, he must be equipped with something of the thought and feeling processes of a director. He must be able to realize within himself three-dimensional animal the writer had in mind. He must be able to manage the external and internal rhythms of the play at one and the same time. Reading a play is not a linear process nor is it the 
comparatively simple task of picturing in the mind's eye and ear, action and words as they are described. The playwright puts into words an inner energy and purpose that threedimensional performance by an actor will bring to life by acting (Bowskill, 1973).

Furthermore, Johan Heuken in Bakdi Soemanto explained that:

...reading and enjoying the stage actively is a "gesalten," "gestaltungsfähig" activity, that is, something that must be formed. On this basis, the discussion on the texture section, the elements in it: dialogue, mood, spectacle are presented together and not separately as in the discussion about structure (Soemanto, 2002).

This statement makes the basis that texture analysis cannot be done separately but must be done together because textures appear simultaneously and influence each other, and have a dialectical relationship.

\section{Methods and Data}

In essence, research is an attempt to find answers to existing problems (Sahid, 2017). Suwardi Endraswara also stated that qualitative research methods have several advantages, namely: adapting qualitative methods more efficiently when dealing with the reality of researchers, presenting the nature of the relationship between researchers and respondents, as well as being more direct and adaptable to many sharpening mutual influences and patterns the pattern of values encountered (Endraswara, 2006).

The research method that the author will use is descriptive. In his book entitled Research Methods, Moh Nazir explains, the descriptive method examines the status of a group of people, an object, a set of conditions, a system of thought, or a class of events. Furthermore, M Nazir added:

Descriptive research studies problems in society and procedures that apply in society and certain situations, including the relationship between activities, attitudes, views, ongoing processes, and the effects of a phenomenon. (Nazir, 1988).

It is by the opinion of Bogdan \& Taylor that qualitative research is a procedure for producing descriptive data (Bogdan \& Taylor, 1993). Qualitative data analysis emphasizes analysis based on statistical relationships on various variables (Alasuutari, 1995). In the qualitative paradigm, the existing data is observed carefully and in detail.

Suwardi Endraswara also stated that qualitative research methods have several advantages. They are adapting qualitative methods more efficiently when dealing with the reality of researchers, presenting the nature of the relationship between researchers and respondents directly, and being more sensitive and able to adapt to many sharpening mutual influences and patterns of behaviour. -the pattern of values encountered (Endraswara, 2006).

\section{Results and Discussion}

Theatre of the absurd has several main points, namely: anti-character, antilanguage, anti-drama, anti-plot (Sharadgeh, 2020; Zhu, 2013). Two short drama texts are used in Putu Wijaya's drapen collection to see the existence of these. To examine these texts, we look at the elements that build them: their structure and texture. It is examined to see if Putu Wijaya's short drama dramaturgically met the rules to be performed on stage.

\section{Untung (2)}

Untung (2) is the title of the ninetyeighth text of a total of one hundred Putu 
Wijaya's short drama. Judging from the title, Untung (2) is a trilogy of 3 short dramas entitled Untung (1) and Untung (3). Untung also means lucky in Bahasa Indonesia.

This text consists of two pages, has two characters, Untung and Ibu. There is only one long line for each character in it. With only two long lines, this text has a lot of possibilities. There are no staging instructions, making this short drama potentially explored by the director and cast or artistic crew.

In the context of absurdity points, it seems that the structure of this text is excluded as an absurd text. The plot is linear and logical like conventional drama. The main thing that distinguishes it is its very short duration. However, structurally, this script has a clear dramatic ladder, the plot is advanced and linear, and the characters can be described psychologically or sociologically (Apriadinnur, 2018).

The texture of the text will appear as an interpretation of its structure. In this script, the textures that exist are highly dependent on the interpretation of the director, performers, or artistic concepts. One of the reasons is that the text is very short, so it will be very ineffective if it is performed singly. Seeing Untung (1) and Untung (3), it seems that Untung (2) was designed as a trilogy and staged successively.

If Untung (2) is performed sequentially with Untung (1) and Untung (3), then Putu Wijaya's idea of the aesthetics of terror will be seen. The repetition of the word Untung as the name of a character and an adjective creates the effect of terror that Putu wants. At this moment, a situation called The Crisis and Cruelty of Human Beings (Zhu, 2013) manifests in itself.

If the Untung $(1,2,3)$ trilogy performances are considered one unit, the structure of the text changes. The plot becomes non-linear, the logic of the character's thinking becomes uncoordinated, and the dramatic becomes non-conventional. The texture of the show will also adjust. The characters' dialogue jumps up and down, the atmosphere becomes unfamiliar and allows for a fluctuating stage spectacle.

\section{Kursi (Chair)}

Kursi (page 415) is written like a staging instruction. Fifteen scenes are briefly described. Although it consists of only four pages, this text provides a lot of possibilities. Without lines, it doesn't mean that this text doesn't have a distinctive plot. Instead, the plot can be seen from the sequence of written instructions. The characteristics of the characters are not explained with certainty.

Structurally, this text can be said to represent the concept of absurdity (Sutjiati et al., 2015). There are no word instructions for players to say, allowing the Kursi to be performed mutely, in mini-words, or full of words. Everything depends on the interpretation of the director, cast, or artistic crew. The forward flow adopted by this text, combined with a precise setting (train station).

The texture of the possible performance gave rise to the nuances of the hustle and bustle of a crowded train station. The setting that represents the train station will bring the players' imagination and the audience to the distinctive atmosphere of the station. Absurdity appears in the scene of the three characters fighting over a chair, sleeping, and several other scenes, which, according to the text's instructions, are like being in their world and being ignored by the surrounding environment.

\section{Conclusion}

Two examples of Putu Wijaya's short plays do not significantly show the concept of absurdity as intended by Martin Esslin when analyzed for structure and texture or if they are performed one by one. The text is not structurally absurd because, in general, it still 
shows the plot, characterizations and setting quite clearly. But it will have different results if the texts are performed consecutively on one stage. It is because all the texts used as examples have a uniform pattern. If the texts are staged sequentially, it will give the effect of repetition, the plot is repeated, and in the end, the terror that Putu Wijaya wants can be achieved.

According to the rules of dramaturgy, the texts in the collection of 100 Drapen Putu Wijaya are very likely to be performed on stage. However, the realization of staging the text one by one is not ideal. It is because the performance of one play will be very short. The most likely option is to stage several series of texts successively until the ideal performance time is reached. It seems that for this reason, Putu Wijaya deliberately made several texts in series.

\section{Reference}

Alasuutari, P. (1995). Researching Culture, Qualitative Method and Cultural Studies. SAGE.

Apriadinnur, R. D. (2018). Pemeranan Tokoh Aku Dalam Naskah My Friend Has Come Karya Toshiro Suzue. TONIL: Jurnal Kajian Sastra, Teater Dan Sinema, 15, 12-21. https://doi.org/https ://doi.org/10.24821/ tnl.v15il.2782

Bogdan, \& Taylor. (1993). Metode Penelitian Kualitatif dan Kuantitatif. Alfabeta.

Bowskill, D. (1973). Acting and Stagecraft : Made Simple. W.H.Allen \& Co. Ltd.

Damono, S. D. (1978). Sosiologi Sastra: Sebuah Pengantar. Pusat Pembinaan Dan Pengembangan Bahasa, Departemen Pendidikan dan Kebudayaan.

Endraswara, S. (2006). Metode, Teori,
Teknik Penelitian Kebudayaan; Ideologi, Epistimologi, dan Aplikasi. Pustaka Widyatama.

Esslin, M. (1967). Theater of the Absurd, revised and enlarged edition. Pelican Books.

Faruk. (1994). Pengantar Sosiologi Sastra. Pustaka Pelajar.

Grotowski, J. (2002). Toward Poor Theater (M. Ariffin (ed.)). MSPI.

Kernodle, G. R. (1967). Invitation to The Theatre. Harcourt, Brace\&World Inc.

Nazir, M. (1988). Metode Penelitian. Ghalia.

Oemarjati, B. S. (1974). Lakon-lakon Pemenang Sayembara Penulisan Naskah Sandiwara 1974, dalam Pesta Seni 1974. Dewan Kesenian Jakarta.

Ratna, K. (2004). Teori, Metode, dan Teknik Penelitian Sastra. Pustaka Pelajar.

Sahid, N. (2017). Sosiologi Teater; Teori dan Penerapannya,. Gigih Pustaka Mandiri.

Sathotho, S. F. (2008). Analisis Struktur dan Tekstur Musuh Masyarakat Karya Henrik Ibsen Terjemahan Asrul Sani. Fenomen, 4(5).

Setijowati, A. (2018). Nyali Karya Putu Wijaya Dalam Perspektif Kekerasan Simbolik Pierre Bourdieu: Sebuah Kajian Hermeutika Paul Ricoeur. Universitas AirLangga.

Sharadgeh, S. Al. (2020). The Theatre of the Absurd. Journal of Studies in Social Sciences, 17, 174-182. https:/infinitypress.info/index.php/jsss/ article/view/1775

Soemanto, B. (2002). Godot di Amerika dan Indonesia, Suatu Studi Banding . Grasindo.

Sutjiati, R., Ningsih, T. W. R., \& Budiwaty, S. (2015). INTERPRETING THE ABSURD THEATRE THROUGH EXISTENTIALISM APPROACH. Prosiding PESAT (Psikologi, Ekonomi, Sastra, Arsitektur \&Teknik Sipil), 6, 
102-107.

https://ejournal.gunadarma.ac.id/index.

php/pesat/article/view/1375/1222

Teeuw, A. (1984). Sastra dan Ilmu Sastra.

Pustaka Jaya.

Wijaya, P. (1982). Gres. Balai Pustaka.

Wijaya, P. (2018). 100 Drapen. Teater Mandiri.

Zhu, J. (2013). Analysis on the Artistic Features and Themes of the Theater of the Absurd. Theory and Practice in Language Studies, 3, 1462-1466. https://doi.org/10.4304/tpls.3.8.14621466 